\title{
Aproximação de um problema: a ficção do leitor nas tramas de Guimarães Rosa
}

- Mestranda em Literatura Francesa (FFLCH-USP).

\author{
Mônica Gama*
}

\section{Resumo}

Este artigo propõe o apontamento de algumas questões relativas à construção da imagem do leitor nas tramas de Guimarães Rosa. Partiremos da percepção de que 0 texto ficcional é composto por uma série de preorientações para sua recepção e também de que na obra de Guimarães Rosa temos como marca constitutiva a ficção de um leitor no texto.

Essa ficção apresenta-se desde Sagarana até Ave, palavra e Estas estórias, livros publicados postumamente. Para entender como se dá essa ficcionalização do leitor, partiremos aqui da análise desse aspecto nos contos "Corpo Fechado", "Desenredo" e "Antiperipléia", o primeiro de Sagarana e os dois últimos de Tutaméia.

Palavras-chave: Guimarães Rosa, ficcionalização, leitor, Tutaméia, Sagarana.

\section{A crítica roseana}

Hscritor consagrado desde o lançamento de seu primeiro livro em 1946, 1 Guimarães Rosa chamou atenção da crítica, principalmente, por sua revolução lingüística e capacidade de fabulação. Desde então, a fortuna crítica sobre sua obra desenvolveu-se de forma ampla e diversificada, sendo possível encontrar nela diversos focos interpretativos: nos recursos estilísticos, nas intençōes esotéricas e metafísicas, nas relações sociológicas, históricas e políticas e no processo de criação. Dentre esses focos, gostaríamos de destacar dois tipos principais: um que trata a obra como uma releitura do regionalismo e outro que valoriza a experimentação lingüística.

Se nos primeiros estudos críticos há uma ênfase interpretativa muito clara na questão regionalista é porque, inegavelmente, Guimarães se filia a um referente geográfico e a um modelo mimético (sertão), que o obrigava a uma pesquisa incessante de palavras, expressóes, hábitos e sonoridades. Contudo, sabemos que não se trata de um retrato da realidade, nem de uma literatura engajada como pretendia a geraçáo de 30, mas sim de uma literatura que a todo momento testa o poder de representação e de inauguração da linguagem.

Ainda assim, consolidou-se uma linha crítica que parte da idéia de mimesis realista, ou ainda, da literatura como resultante de uma represen-

' HANSEN, J. A. 0 o: a fição da literatura em Grande sertão: veredas. São Paulo: Hedra, 2000. tação testemunhal, ou seja, que se pretende representação verdadeira do mundo. Hansen chega a afirmar que essa crítica "não sai dos limites do efeito do real produzido no texto e pelo texto"1. 
O segundo foco interpretativo concentra-se na idéia da experimentação lingüística, pois ela é, sem dúvida, um dos aspectos mais marcantes da obra roseana e, por isso, tão explorado pela crítica através da retomada de arcaísmos, da exploração dos neologismos, da absorção de elementos da oralidade etc.; todos esses processos, somados aos elementos próprios da construção poética, resultam num trabalho de desautomatização da língua. Assim, a revolução política pensada pela geração anterior é, para Rosa, uma revoluçáo que precisa começar pela mudança da estrutura lingüísti$\mathrm{ca}^{2}$. Contudo, em busca de especificidades do texto roseano procura-se, a partir da idéia de ruptura, analisar seu projeto ficcional. Daí ser muito pertinente a crítica elaborada por Hansen: os efeitos de ruptura extraídos de exemplos lingǘsticos de rompimento de uma "presumida norma lingüistica do Português do Brasil" produzem certa confusão:

confunde-se certo material semiótico disponível — o signo, sua refração contraditória - com o objeto literário produzido; confunde-se um fato da língua com um fato de literatura; hipostasia-se em código o que é discurso, quando se valorizam os procedimentos e não se valorizam as práticas produtivas $(. .)^{3}$

Assim, valorizando o procedimento de ruptura esquece-se do efeito provocado: a desautomatizaçáo da língua, cujo efeito concorre para o estranhamento no leitor, seja pela apontada dificuldade de entendimento lingüístico, seja pela reordenação de modelos literários — por exemplo a novela que é chamada de poema ou o conto que também é um prefácio.

Em geral, há um certo consenso em admitir a importância elevada do papel do leitor na obra roseana, como aquele que deve decifrar o texto pleno de estruturas enigmáticas. Contudo, esse elemento do dispositivo narrativo é somente citado, mas náo trabalhado pela crítica. Todo o estranhamento provocado no leitor em relação à representação ficcional é afirmado e vangloriado apenas como resultado de uma ficção engenhosa.

Podemos rastrear essa preocupação do autor com o leitor desde Sagarana, de 1946, até Tutaméia, de 1967. Durante todo seu percurso ficcional, Rosa construirá diversas imagens de interlocutores-leitores, indo do doutor que toma notas, para o crítico literário que observa sua construção.

\section{0 diálogo em Sagarana}

Acreditando ser necessário o rastreamento da imagem do leitor em sua obra, procuramos algumas de suas especificidades. A primeira é: na maior parte dessas narrativas, a ficção do receptor se dá como ouvinte e não como leitor - não podemos esquecer que a oralidade é um dos grandes instrumentos de Guimarăes para nos levar ao sertão.

Motivada por essa questão da oralidade é que gostaria agora de tentar identificar o narrador roseano. Para tanto farei o esboço de uma análise do conto "Corpo Fechado" de Sagarana.

Escolhi esse texto porque a interlocução entre narrador e ouvinte se dá de maneira exemplar. O conto apresenta-se estruturalmente em três movi-
2 É preciso citar sobretudo os trabalhos de Pedro Xisto, Augusto e Haroldo de Campos.

${ }^{3}$ Idem, p. 27. 
mentos. O primeiro limita-se até o final de uma pequena narração sobre a morte do valentão José Boi, dando a impressão de que se trata de uma narrativa em terceira pessoa. Contudo, logo se inicia um diálogo entre esse primeiro narrador e Manuel Fulô sobre os valentôes da cidade e também sobre algumas de suas aventuras. Por último, temos a retomada da voz do primeiro narrador contando como chegou na cidade e a última e maior aventura de Manuel.

A maior parte do conto é constituída por esse segundo movimento, caracterizado pela forma dialogal. Trata-se de um narrador em primeira pessoa que dialoga com uma personagem que narra muitas estórias, ou seja, trata-se de dois personagens que desempenham o papel de narradores.

O narrador efetivo em primeira pessoa é quem questiona e organiza as idéias, proporcionando logo de início uma identificação direta com o leitor: parece que somos nós os questionadores de Manuel Fulô:

- Você o conheceu, Manuel Fulô?

- Mas muito!... Bom homem... Muito amigo meu. Só que ele andava sempre coçando a cabeça, e eu tenho um medo danado de piolho...

- Podia ser sinal de indecisão...

- Eu acompanhei até o enterro. Nunca vi defunto tão esticado de comprido... caixão especial no tamanho: acho que levou mais de peça e meia de galão...

- E quem tomou o lugar dele?

- Lugar? O sujeito não tinha cobre nem p'ra um bom animal de sela... o que ganhava ia na pinga... mão aberta...

- Mas, quem ficou sendo o valentão, depois que ele morreu?

- Ah, isso teve muitos: o Desidério...

(...)

- E o tal do Dêjo?

- Esse veio depois... antes teve o Miligido... e o nome daquele era Adejalma, nome bobo, que nem é de santo...um peste. Muita prosa, muita farroma, mas eu virei o cujo do avesso! Me respeitou! Me respeitou, seu doutor!

- Briga, Manuel?

- Lhe conto, seu doutor. Foi na venda: eu estava comprando cadarço de roupa, coisa de paz... O homem já veio chegando enjoado, me olhando com cara de herege... Negaceou. Depois, virou p'ra Percio, que era caixeiro nesse tempo. E perguntou; "O senhor tem aí dessa raça de faca que entra na barriga e murguêia?" E olhou p'ra mim, outra vez, pra ver se eu estava com receio...

- E você, Manuel Fulô?

- Eu ia serra de cima, mas nem não tive tempo, porque nessa horinha vinha entrando um tropeiro de Soledade, que era homem duro, e pensou que a ofensa era p'ra ele... e aquilo foi o tropeiro dando um murro no balcão, e tossindo, e perguntando também p'ra o Pércio: "Por falar nisso, o senhor não terá também dessa raça de bala que bate na testa e chateia?!" Pois aí o Adejalma se riu de medo, e disse que estava era brincando....

- Mas, então, Manuel, como foi que você virou o Dêjo pelo avesso?

${ }^{4}$ ROSA, J. G. Sagarana. Rio de - Ara, ara, seu doutor! Se o tropeiro não tivesse entrado, eu fazia desordem, e fazia mesmo...4 
Esse questionador é caracterizado como "gente da cidade", usa gravata e é chamado de "seu doutor". Ora, pensamos diretamente em Guimarães Rosa que durante algum tempo foi médico em Itaguara, uma cidadezinha de Minas Gerais. Ele era esse elemento externo, estranho dentro daquele meio, ou seja, o homem letrado que ocupava uma posição de destaque, ansioso e curioso por conhecer aquelas histórias.

Logo após esse trecho, conta que certa vez desconfiou de uma das estórias de Manuel, mas logo percebeu que havia errado e que seria preciso ter confiança em seus causos. A característica desse contador é o gosto pela conversa fiada e, nelas, Fulô sempre se coloca como um valentão, contradizendo totalmente sua condição de bêbado e relaxado, ou, como afirma "seu doutor", vivia na "mais concreta abstração". Podemos até afirmar que sua única preocupação era com sua mula Beija-Fulô que "era seu complemento: juntos, centaurizavam gloriosamente".

Assim como esse primeiro narrador, o "doutor", nós também desconfiamos das narrativas de Manuel, mas ele tem o talento de contar estórias, é o próprio narrador descrito por Benjamin - perceberemos então que o narrador roseano está na interface entre o narrador tradicional e o do romance moderno.

Benjamin descreve a arte de narrar em oposição ao romance, trabaIhando sempre a tese de que aquela está se tornando extinta e suplantada por esta. $\mathrm{O}$ narrador retira seu contar da experiência (dele mesmo ou de outros) e sempre procede da tradição oral. Além disso, ele incorpora o narrado às experiências de seus ouvintes. Já o romance "nem procede da tradição oral, nem a alimenta (...) [sua] origem é o indivídue isolado"s.

Afirma também que a narrativa desse contador tem uma "dimensão utilitária" já que "é o homem que sabe dar conselhos". Mas acusa a falta de comunicabilidade moderna para anunciar a morte do fornecimento de conselhos. Entenda-se que "aconselhar é menos responder a uma pergunta que fazer uma sugestão sobre a continuação de uma história que está sendo narrada (...) a arte de narrar está definhando porque a sabedoria — o lado épico da verdade - está em extinção" .

Encontramos em Rosa outra característica descrita por Benjamin, a presença da narração do saber que vem de longe em oposição ao acúmulo de informações; em nosso caso, temos o sertão como esse longe desconhecido e o homem urbano como representante de uma literatura que aspira as informaçōes e organiza as idéias para um leitor que não é mais aquele preparado para todo tipo de narração.

Mas é claro que também não estamos identificando o narrador roseano totalmente com esse narrador de Benjamin. Trata-se de um escritor contemporâneo que tem sua produção literária imantada pelo código artístico atual.

Já na época do lançamento de Sagarana, Antonio Candido apontava para a complexidade desse narrador. Sublinhou a paixão de contar e o domínio narrativo de Guimarães: "o sr. Guimarães Rosa retorna, em grande estilo, à concepção do contista-narrador, para o qual a verdade está na narração e na descrição, para o qual as facadas, os casos de amor, os estouros de boiada e os crepúsculos têm valor eterno, acima de quaisquer outros"7.
'BENJAMIN, W. "O narrador". In: Magia e técnica, arte $e$ política. São Paulo: Brasiliense, 1993, p. 201.

${ }^{6}$ Idem, p. 200.

\footnotetext{
7 CANDIDO, Antonio. "Sagarana". In: COUTINHO, Eduardo. Guimarães Rosa. Rio de Janeiro: Civilização Brasileira/Pró-Memória/ Instituto Nacional do Livro, 1983.
} 
Em "Corpo Fechado" percebemos que há uma tematização da diferença narrativa e também da atitude da leitura, ou seja, trata-se da ficção de um leitor que permanece na tensão entre esses dois registros narratários - vale dizer que ao mesmo tempo em que acompanhamos os questionamentos do doutor e nos identificamos com ele, somos levados pelas estórias de Manuel Fulô.

Essa duplicidade de percepçóes na recepção do texto é resultado de uma dupla ficcionalizaçáo do narrador operada pelo autor: por um lado temos o narrador efetivo, o doutor, como uma ficção do próprio Rosa, um indivíduo que age a partir de um método - ele anota desejando recuperar essa tradição oral que sente estar em decadência, se não, por que anotar e preservar?

Pois foi nesse tempo calamitoso que eu vim para Laginha, de morada, e fui tomando de tudo a devida nota.

O arraial era o mais monótono possível. Logo na chegada, ansioso por conversas à beira do fogo, desafios com vioła, batuques e cavalhadas, procurei, procurei, e quebrei a foice. As noites, principalmente, impressionavam (...) o responso pluralíssimo dos sapos. Um só latido, mágico, feito por muitos cachorros remotos. Grilos finfininhos e bezerros fonfonando. E pronto ${ }^{8}$.

Por outro lado, sabendo que está em extinção a sabedoria do contador, ficcionaliza um outro narrador que entrará na narrativa sempre em diálogo com outrem que o possibilite. É como se admitisse que Fulô não pode mais fazer saber-se por si, pois se ele tem competência para narrar, não há mais a coletividade que o escute.

Daí entendermos que o procedimento de Rosa se baseia na tentativa de recuperação desse narrador tradicional, mas que, na impossibilidade de sua autonomia, só pode fazê-lo por sua ficcionalização.

\section{Os enigmas em Tutaméia}

Tutaméia, última obra publicada em vida, apresenta de forma intensa os resultados do longo exercício de estranhamento procurado por Guimarães desde seus primeiros livros. Dito assim parece que caímos na armadilha do pensamento evolucionista, mas não se trata disso. Sabemos que sua obra mais consagrada é Grande sertão: veredas e, como tal, ela revê ao mesmo tempo em que projeta o que pensamos da obra total do autor - dito de outra maneira: a recepção desta obra modifica a recepção das outras, anteriores e posteriores a sua leitura. Dessa forma, enquanto as memórias de Riobaldo são entremeadas de várias outras estórias, numa colcha de retalhos de narrativas, discussóes estéticas e especulações filosóficas e religiosas, mediadas pelo grande monólogo do narrador e personagem principal, em Tutaméia Rosa apresenta a mesma pluralidade, mas agora caracterizada pela diluição de narrativas em 44 curtos contos de alta densidade poética e que trabalham, sobretudo, com o mínimo e com a desconstrução - quatro deles são renomeados posteriormente (num segundo índice de leitura) como prefácios. 
Tudo no livro pede uma leitura diferenciada: a duplicidade do título - Tutaméia (Terceiras estórias); a epígrafe junto ao índice; a presença de quatro prefácios; a inversão dos títulos; um texto que traz um glossário de palavras não utilizadas; o índice de releitura junto à outra epígrafe no final do livro. É claro que um leitor habitual de Guimaráes - acostumado a um romance sem capítulos, novelas que são apresentadas no índice como poẹmas, uma coletânea de contos que traz um segundo índice iconográfico - pode não se assustar tanto, mas esses elementos demarcam um espaço do estranhamento?.

Novamente encontramos uma ficção do receptor como ouvinte e não como leitor. Vimos rapidamente o caso de um conto de Sagarana, mas podemos citar ainda outros exemplos, como Grande sertão: Veredas. Este encena um grande diálogo, uma vez que existe a imagem do outro que escuta (marcada por intervençóes como: "o senhor ri certas risadas"), e um enorme monólogo - já que só temos acesso à voz de Riobaldo.

O mesmo acontece, por exemplo, com o conto "Desenredo" de Tutaméia, sendo um dos textos mais exemplares para a compreensão tanto da posiçáo do narrador, quanto do leitor, pois pensamos que ele talvez consiga apontar para essa tensão quanto ao narratário.

A primeira frase do conto, "do narrador a seus ouvintes", segue o modelo roseano de demonstrar sua consciência de ficcionalidade. Entretanto, se temos anunciado um narrador tal como nos moldes descritos acima (e, portanto, também o ouvinte-leitor), a partir de então somos abandonados para a área somente da expectativa, pois agora temos um narrador em terceira pessoa onisciente, tão conhecido e aceito sem contestaçôes.

Além disso, é sua construção metafórica o que nos impulsiona a pensar o leitor nesse conto. Acredito tratar-se de uma poética da leitura; a temática do conto participa organicamente da estruturação do livro, ou seja, a da releitura. Trata-se da estória de amor entre Jô Joaquim e uma mulher com nominação variável (Livíria, Rivília, Irlívia ou Vilíria) que o trai diversas vezes, mas que é inocentada pelo amante através de sua capacidade de reinventar o passado. Mais que uma estória de amor, é uma poética de releitura e de invenção ficcional:

Nunca tivera ela amantes! Não um. Não dois. Disse-se e dizia isso Jó Joaquim. Reportava a lenda a embustes, falsas lérias escabrosas. Cumpria-lhe descaluniála, obrigava-se por tudo. Trouxe a boca-de-cena do mundo, de caso raso, o que fora tão claro como água suja. (...) sem malícia, com paciência, sem insistência, principalmente. (...) o ponto está em que o soube, de tal arte: por antipesquisas, acronologia miúda, conversinhas escudadas, remendados testemunhos. Jô Joaquim, genial, operava o passado - plástico e contraditório rascunho. Criava nova, transformada realidade, mais alta. Mais certa? ${ }^{10}$

Assim, o leitor de Tutaméia é levado, ao final de sua leitura, a redimensionar tudo o que leu, levando em conta o suposto hermetismo dos contos (acusação de diversos leitores que não nos cabe agora discutir), a partir da afirmação do autor sobre a necessidade de revisitação de seus textos pelas
${ }^{9}$ É de se notar também que a crítica substancial encontra-se centralizada nas obras anteriores.

${ }^{10}$ ROSA, J. G. Tutaméia. Rio de Janeiro: José Olympio, 1967. 
que, examinando novamente os fatos, recria uma estória "operando o passado" - que nada mais é que um "contraditório rascunho".

"Antiperipléia" é o segundo texto da coletânea ou, se preferirmos, é o primeiro conto já que "Aletria e Hermenêutica" é um prefácio. Neste conto também encontramos um diálogo monológico: todo o texto contém apenas a fala desse eu que náo cede a voz ao outro que, por sua vez, pode ser identificado como nós mesmos, leitores. A primeira frase traz indiretamente a fala desse outro ouvinte: "- E o senhor quer me levar, distante, às cidades?". Essa pergunta, feita anteriormente pelo outro e repetida pelo narrador, inaugura o conto, mas não será respondida rapidamente. $O$ restante da narrativa é a resposta: o "delongo", ou seja, adio, retardo. Todo o conto será esse movimento de retardamento da resposta exigida pelo interlocutor.

Novamente temos a metáfora do leitor como aquele que retrocede. Assim como uma "viagem de volta", o narrador começa contar sua estória de guia de cego de seô Tomé e como sua vida mudou depois da morte misteriosa deste. Era comum as mulheres gostarem do cego, e este sempre perguntava ao seu guia se ela era ou não bonita. Antes da morte, uma mulher apaixonara-se perdidamente pelo cego, mas esta era casada e feia, "apesar dos poderes de Deus"; ela convence o guia a mentir sua feiúra para seô Tomé. $\mathrm{O}$ engodo funciona e os dois vivem bem por um tempo. Contudo, vem a morte misteriosa do cego e é o guia o maior suspeito. Este, por sua vez, pulveriza as possibilidades: pode ter sido a mulher por medo de ser abandonada pelo cego, pois este dissera que voltara a ver; podemos pensar no marido traído, e ainda num suicídio, pois Tomé podia estar vendo que sua amada era bem diferente do prometido. Todas essas possibilidades são nos dadas pelo guia, por isso temos espaço aberto para a desconfiança.

Guiados por esse narrador duvidoso, os leitores são colocados diante do enigma da morte do cego. O que nos resta é a árdua e prazerosa tarefa de reler a trama para tentarmos esclarecer o mistério. Parece que podemos ver novamente aqui uma leitura metafórica do receptor da obra: o leitor é como um cego guiado por outrem, mas que, na dúvida sobre até que ponto sua percepção corresponde ou não a de seu guia, é anulado, tornando-se apenas elemento de revisitação. E o recado ao crítico literário parece ser dado: "cego suplica de ver mais do que quem vê", e mais adiante: "o pior cego é o que quer ver".

Esperamos ter conseguido esboçar a problematização da construção da metaforização do leitor na obra de Guimarães. É preciso discutir o papel desempenhado pelo narrador e pela ficçáo do leitor para entendermos como se dá o funcionamento da máquina de sentido ficcional própria desse autor. Isso porque essas construções dão a ver a tensão entre autor, narrador e leitor - categorias que precisam de mais atençáo quando pensamos o caso roseano.

\section{Abstract}

This article proposes the discussion of some questions related to the construction of the reader as an image in the fiction of Guimarães Rosa - the fictionalization of the role of the reader is one of Rosa's hallmarks. 